\title{
ANALISIS PENERAPAN PSAK NO. 45 TENTANG PELAPORAN KEUANGAN ORGANISASI NIRLABA PADA UTD KABUPATEN PEKALONGAN
}

\author{
Rizka Ariyanti*, Laely T Soraya \\ Prodi Akuntansi Politeknik Pusmanu \\ Korespondensi: rizkaariyanti81@gmail.com
}

\begin{abstract}
Financial reporting as a decision-making aid must be recognized by all parties from all aspects, both forprofit organizations and non-profit organizations. The purpose of financial reports is to provide relevant information to meet the interests of organizational members, creditors and other parties who provide resources to non-profit organizations. This study aims to describe the preparation of the financial statements of the PMI Pekalongan Regency Blood Transfusion Unit as a non-profit organization with reference to PSAK No. 45. The location of this study is UTD PMI Regency, with research subjects Staff of the Finance and Administration Sub Division of Blood Transfusion Unit of PMI Pekalongan Regency.Data collection techniques used are through observation, documentation and interviews. The data analysis method used in this research is descriptive qualitative, by comparing theory and practice in the preparation of organizational financial reports. The results showed that overall, UTD PMI Pekalongan Regency has referred to the provisions of PSAK No. 45 regarding the financial reporting of non-profit organizations, but there is 1 indicator in the financial statements of UTD PMI Pekalongan Regency that is not in accordance with PSAK No. 45, namely the classification of liabilities that have not been grouped into short-term and long-term liabilities.
\end{abstract}

Keywords: Application of PSAK No. 45, Financial Reporting, Nonprofits,

\section{PENDAHULUAN}

Pelaporan keuangan sebagai alat bantu pengambilan keputusan harus disadari oleh semua pihak dari segala aspek baik organisasi yang mencari laba maupun organisasi nirlaba. Tujuan laporan keuangan adalah menyediakan informasi yang relevan untuk memenuhi kepentingan para anggota organisasi, kreditur dan pihak lain yang menyediakan sumber daya bagi organisasi nirlaba. Pihak pengguna laporan keuangan organisasi nirlaba memiliki kepentingan bersama dalam rangka menilai (IAI, 2009): jasa yang diberikan oleh organisasai nirlaba dan kemampuannya untuk terus memberikan jasa tersebut. Pelaporan keuangan pada organisasi nirlaba tidak hanya diperlukan untuk pengambilan keputusan saja, akan tetapi sebagai perwujudan pertanggung jawaban akuntanbilitas organisasi tersebut.

Karakteristik entitas nirlaba berbeda dengan entitas bisnis. Perbedaan utama yang mendasar terletak pada cara entitas nirlaba memperoleh sumber daya yang dibutuhkan untuk melakukan berbagai aktivitas operasinya. Entitas nirlaba memperoleh sumber daya dari sumbangan para anggota dan para penyumbang lain yang tidak mengharapkan imbalan apapun dari entitas nirlaba tersebut.

Sebagai akibat dari karakteristik tersebut, dalam entitas nirlaba timbul transaksi tertentu yang jarang atau bahkan tidak pernah terjadi dalam entitas bisnis, misalnya penerimaan sumbangan. Namun demikian, dalam praktik entitas nirlaba sering tampil dalam berbagai bentuk, sehingga sering kali sulit dibedakan dengan entitas bisnis pada umumnya. Beberapa bentuk entitas nirlaba, meskipun tidak ada kepemilikan, entitas nirlaba tersebut mendanai kebutuhan modalnya dari utang, dan kebutuhan operasinya dari pendapatan atas jasa yang diberikan kepada publik. Akibatnya, pengukuran jumlah, saat dan kepastian aliran kas masuk menjadi ukuran kinerja penting bagi 
para pengguna laporan keuangan entitas nirlaba tersebut, seperti kreditur dan pemasok dana lainnya. Entitas semacam ini memiliki karakteristik yang tidak jauh berbeda dengan entitas bisnis pada umumnya.

Unit Transfusi Darah, yang selanjutnya disingkat UTD, adalah fasilitas pelayanan kesehatan yang menyelenggarakan pendonor darah, penyediaan darah, dan pendistribusian darah. UTD PMI Kabupaten Pekalongan sampai dengan saat ini sudah memiliki laporan keuangan, namun menurut bagian keuangan pada UTD PMI Kabupaten Pekalongan memang belum memahami betul terkait PSAK No. 45 yang mengatur tentang pelaporan keuangan organisasi nirlaba, sehingga di sini peneliti tertarik untuk mengadakan penelitian tentang laporan keuangan pada UTD PMI Kabupaten Pekalongan sudah sesuai dengan PSAK No 45 tentang pelaporan Keuangan Organisasi Nirlaba.

Rumusan masalah dalam penelitian ini yaitu apakah UTD PMI Kabupaten menyusun laporan keuangan sudah sesuai dengan PSAK No 45 tentang pelaporan Keuangan Organisasi Nirlaba. Adapun pertanyaan penelitian (research question) yang diajukan dalam penelitian ini adalah sebagai berikut: Apakah Pelaporan Keuangan UTD PMI Kabupaten Pekalongan telah mengacu pada PSAK No 45 tentang pelaporan keuangan organisasi nirlaba.

\section{Rumusan Masalah}

Rumusan masalah dalam penelitian ini yaitu apakah unit transfuse darah (UTD) PMI Kabupaten Pekalongan dalam menyusun laporan keuangan sudah sesuai dengan PSAK N0 45 tentang Pelaporan Keuangan Organisasi Nirlaba. Adapun pertanyaan penelitian (research questions) yang diajukan dalam penelitian ini adalah sebagai berikut:

Apakah pelaporan keuangan unit transfusi Darah (UTD) PMI Kabupaten Pekalongan telah mengacu pada ketentuan PSAK No 45 tentang Pelaporan Keuangan Organisasi nirlaba?

\section{STANDAR AKUNTANSI KEUANGAN}

Standar Akuntansi Keuangan merupakan pengumuman resmi yang dikeluarkan oleh badan yang berwenang. Standar akuntansi keuangan memuat konsep standar dan metode yang dinyatakan sebagai pedoman umum dalam praktik akuntansi perusahaan dalam lingkungan tertentu.Standar ini dapat diterapkan sepanjang masih relevan dengan keadaan perusahaan yang bersangkutan.

Akuntansi keuangan di Indonesia disusun oleh Dewan Standar Keuangan yaitu Ikatan Akuntan Indonesia (IAI) Indonesia juga sudah memiliki kerangka dasar penyusunan dan penyajian laporan keuangan yang merupakan konsep sebagai dasar penyusunan dan penyajian laporan keuangan bagi para pihak eksternal pemakai laporan keuangan tersebut. Jika terdapat pertentangan antara kerangka dasar dan Standar Akuntansi Keuangan maka ketentuan Standar Akuntansi Keuangan yang harus diunggulkan relatif terhadap kerangka dasar ini. Karena kerangka dasar ini dimaksudkan sebagai acuan bagi Komite Penyusun Standar Akuntansi Keuangan dalam mengembangkan Standar Akuntansi Keuangan di masa datang dan dalam peninjauan kembali terhadap Standar Akuntansi Keuangan yang berlaku.

Secara garis besar ada empat hal pokok yang diatur dalam Standar Akuntansi Keuangan yaitu:

a) Pengakuan unsur laporan keuangan

Pengakuan merupakan proses pembentukan suatu pos yang memenuhi definisi unsur serta kriteria pengakuan yang dikemukakan dalam neraca atau laba rugi. Pengakuan dilakukan dengan menyatakan pos tersebut dengan kata-kata maupun dalam jumlah uang dan mencantumkannya ke dalam 
neraca atau laporan laba rugi. Pos yang memenuhi definisi suatu unsur diakui jika :

1. Ada kemungkinan bahwa manfaat ekonomi yang berkaitan dengan pos tersebut akan mengalir dari atau ke dalam perusahaan;

2. Pos tersebut mempunyai nilai atau biaya yang dapat diukur dengan andal.

b) Definisi elemen dan pos laporan keuangan

c) Pengukuran unsur laporan keuangan

Pengukuran adalah proses penetapan jumlah uang untuk mengetahui setiap laporan keuangan dalam neraca dan laporan keuangan laba rugi. Proses ini menyangkut dasar pemilihan tertentu.

d) Pengungkapan atau penyajian informasi

keuangan dalam laporan keuangan

\subsection{Standar Akuntansi Keuangan Organisasi Nirlaba \\ Pernyataan Standar Akuntansi Keuangan}

No. 45 merupakan standar khusus untuk organisasi nirlaba. Karakteristik organisasi nirlaba sangat berbeda dengan organisasi bisnis yang berorientasi untuk memperoleh laba. Perbedaan terletak pada cara organisasi memperoleh sumber daya yang dibutuhkan untuk melakukan berbagai aktivitas operasionalnya. Organisasi nirlaba memperoleh sumber daya dari sumbangan para anggota dan penyumbang lain yang tidak mengharapkan imbalan apapun dari organisasi yang bersangkutan.

Sebagai akibat dari karakteristik tersebut, dalam organisasi nirlaba timbul transaksi tertentu yang jarang atau bahkan tidak pernah terjadi dalam organisasi bisnis, contohnya penerimaan sumbangan. Pada beberapa bentuk organisasi nirlaba meskipun tidak ada kepemilikan, organisasi tersebut mencukupi modalnya dari hutang dan mendanai kegiatan operasionalnya dari pendapatan atas jasa yang diberikan kepada publik. Akibatnya pengukuran jumlah, saat dan kepastian aliran pemasukan kas menjadi ukuran kinerja yang penting bagi para pengguna laporan keuangan organisasi tersebut, seperti kreditur dan pemasok dana lainnya. Berikut ini adalah pengertian-pengertian menurut Pernyataan Standar Akuntansi Keuangan Nomor 45 :

a) Tujuan Laporan Keuangan

Tujuan Iaporan keuangan adalah menyediakan informasi yang relevan untuk memenuhi kepentingan para penyumbang, anggota organisasi, kreditur dan pihak lain yang menyediakan sumber daya bagi organisasi nirlaba. Pihak pengguna Iaporan keuangan organisasi nirlaba memiliki kepentingan bersama dalam rangka menilai (IAI, 2009) :

1. Jasa yang diberikan oleh organisasi nirlaba dan kemampuannya untuk terus memberikan jasa tersebut;

2. Cara manajer melaksanakan tanggung jawabnya dan aspek lain darikinerja mereka.

Secara rinci, tujuan laporan keuangan termasuk catatan atas laporan keuangan, adalah untuk menyajikan informasi mengenai:

1. Jumlah dan sifat aset, kewajiban, dan aset bersih suatu organisasi;

2. Pengaruh transaksi, peristiwa, dan situasilainnya yang mengubah nilai dan sifat aset bersih;

3. Jenis dan jumlah arus masuk dan arus keluar sumber daya dalam suatu periode dan hubungan antara keduanya;

4. Cara suatu organisasi mendapatkan dan membelanjakan kas, memperoleh pinjaman dan melunasi pinjaman, dan faktor lainnya yang berpengaruh pada likuiditasnya;

5. Usaha jasa suatu organisasi.

b) Unsur-Unsur Laporan Keuangan Nirlaba

Laporan keuangan organisasi nirlaba menurut Pernyataan Standar Akuntansi Keuangan No. 45 meliputi laporan posisi keuangan pada akhir periode laporan. Tujuan 
laporan posisi keuangan adalah untuk menyediakan informasi mengenai aset, kewajiban dan aset bersih, serta mengetahui hubungan di antara unsur-unsur tersebut pada waktu tertentu. Laporan posisi keuangan, termasuk catatan atas laporan keuangan, menyediakan informasi yang relevan mengenai likuiditas, fleksibilitas keuangan, dan hubungan antara aset dan kewajiban. Informasi tersebut umumnya disajikan dalam pengumpulan aset dan kewajiban yang memiliki aktivitas serupa dalam suatu kelompok yang relatif homogen.

c) Klasifikasi Aset Bersih

Laporan posisi keuangan menyajikan jumlah masing-masing kelompok aset bersih berdasarkan ada tidaknya pembatasan oleh penyumbang, yaitu terikat secara permanen, terikat secara temporer, dan tidak terikat. Pengertian istilah yang digunakan adalah sebagai berikut:

1. Pembatasan permanen adalah pembatasan penggunaan sumber daya yang ditetapkan oleh penyumbang agar sumber daya tersebut dipertahankan secara permanen, tetapi organisasi diizinkan untuk menggunakan semuanya atau sebagian atau manfaat ekonomi lainnya yang berasal dari sumber daya tersebut;

2. Pembatasan temporer adalah pembatasan penggunaan sumber daya oleh penyumbang yang menetapkan, agar sumber daya tersebut dipertahankan sampai periode tertentu atau sampai dengan terpenuhinya keadaan tertentu;

3. Sumbangan terikat adalah sumber daya yang penggunaannya dibatasi untuk tujuan tertentu olehpenyumbang. Pembatasan tersebut dapat bersifat permanen atau temporer;
4. Sumbangan tidak terikat adalah sumber daya yang penggunaannya tidak dibatasi untuk tujuan tertentu oleh penyumbang.

Aset bersih tidak terikat umumnya meliputi pendapatan jasa, penjualan barang, sumbangan dan deviden atau hasil investasi, dikurangi beban untuk memperoleh pendapatan tersebut. Batasan terhadap penggunaan aset bersih tidak terikat dapat berasal dari sifat organisasi, lingkungan operasional, dan tujuan organisasi yang tercantum dalam akta pendirian dan dari perjanjian kontrak dengan organisasi lain. Informasi mengenai batasan-batasan tersebut umumnya disajikan dalam catatan atas laporan keuangan

Unit Transfusi Darah Kabupaten Pekalongan merupakan organisasi yang bergerak di bidang sosial dengan fasilitas pelayanan kesehatan yang menyelenggarakan pendonor darah, penyediaan darah dan pendistribusian darah. Penelitian ini menganalis penyajian laporan keuangan yang dilakukan di UTD PMI Kabupaten Pekalongan dengan mengacu pada ketentuan PSAK No.45 tentang Pelaporan Keuangan Organisasi Nirlaba. Sehingga dari laporan hasil penelitian dapat diketahui Apakah UTD PMI Kabupaten Pekalongan ini sudah menerapkan sepenuhnya ketentuan yang ada pada PSAK No.45 tentang pelaporan keuangan organisasi nirlaba atau tidak.

Kerangka pemikiran sebagaimana diuraikan di atas dapat digambarkan sebagai berikut : 


\section{\begin{tabular}{|c|}
\hline $\begin{array}{c}\text { Lap Keuangan } \\
\text { UTD PMI }\end{array}$ \\
$\downarrow$ \\
$\begin{array}{c}\text { Analaisis Kesesuaian terhadap } \\
\text { PSAK No 45 Tentang Pelaporana } \\
\text { organisasi Nirlaba }\end{array}$ \\
$\downarrow$ \\
\hline Sesuai / Tidak Sesuai \\
\hline
\end{tabular} \\ Sumber : berbagi jurnal diolah \\ Gambar 1. Kerangka Berpikir}

\section{METODE}

Untuk memperoleh data yang berhubungan dengan penelitian maka metode pengambilan data dilakukan dengan cara mengambil langsung data di tempat penelitian dengan cara:

\subsection{Observasi}

Observasi dilakukan peneliti selama 1 bulan secara langsung, data yang dikumpulkan diperoleh dari bidang pelayanan dan penagihan di unit kerja.

\subsection{Wawancara}

Wawancara yang dilakukan oleh peneliti dilakukan secara semi terstruktur artinya kalimat dan urutan yang diajukan peneliti tidak harus mengikuti ketentuan secara ketat.

\subsection{Studi Pustaka}

Studi pustaka dilakukan dengan mempelajari dan membaca berbagai peraturan perundangan serta bahan-bahan pustaka yang berkaitan dengan kajian penerimaan pajak reklame.Selain berupa peraturan dan buku, sumber data juga diambil dari internet.

Analisis data kualitatif yaitu menguraikan serta menginterpretasikan data yang diperoleh di lapangan dari para informan. Dalam penelitian ini, penulis menganalisis secara langsung data-data yang peneliti peroleh ketika melakukan observasi dan wawancara. Datadata yang diperoleh akan diolah dan disajikan dalam bentuk deskriptif yang bertujuan untuk mengemukakan permasalahan dan menemukan solusi dengan disertai dengan teori-teori yang mendukung yaitu:

a) Pengumpulan Data

Pengumpulan data yaitu mengumpulkan data yang ada di lokasi penelitian dengan melakukan observasi, wawancara, dokumentasi dan studi pustaka dengan menentukan strategi pengumpulan data yang tepat dan menentukan fokus serta pendalaman data pada proses pengumpulan data berikutnya. b) Reduksi Data

Data yang diperoleh dari observasi, wawancara dan dokumentasi dicatat dengan rinci dengan memfokuskan dan memilih halhal yang penting, sehingga data yang diperoleh dapat memberikan gambaran yang jelas mengenai topik yang sedang diteliti.

c) Penyajian Data

Setelah melakukan reduksi data, penulis menyajikan data dalambentuk teks yang bersifat deskriptif.

\section{d) Penarikan Kesimpulan}

Setelah data-data terangkum dan dijabarkan, penulis akan membuat kesimpulan yang nantinya dapat digunakan untuk menjawab rumusan masalah

\subsection{Analisis Kualitatif}

Analisis Kualitatif yaitu analisis yang dilakukan dengan membandingkan antara teori dan praktik dalam penyusunan laporan keuangan organisasi. Pada analisis ini dilakukan pembandingan apakah format laporan keuangan telah disajikan sesuai dengan PSAK 45 atau masih perlu dilakukan penyesuaian yang nantinya dideskripsikan sesuai hasil analisis di lapangan, apabila penyajian laporan keuangan telah sesuai dengan ketentuan-ketentuan dalam PSAK No. 45 maka penyajian akun tersebut dikatakan sesuai. Apabila penyajian laporan keuangan belum sesuai dengan ketentuan-ketentuan 
dalam PSAK No. 45 maka penyajian akun tersebut dikatakan tidak sesuai dan sebaiknya perlu dilakukan penyesuaian agar semua data ekonomi dapat tersaji dengan baik sehingga memudahkan bagi pihak-pihakyang berkepentingan dalam menginterpretasikan dan mengevaluasi penyajian laporan keuangan tersebut guna mengambil keputusan ekonomi yang baik bagi tiap-tiap pihak.

\section{HASIL DAN PEMBAHASAN}

\subsection{Komponen Pelaporan yang Digunakan}

Tabel 1. Analisis Komponen Pelaporan yang Digunakan UTD PMI Kabupaten Pekalongan berdasarkan PSAK No. 45

\begin{tabular}{|c|c|c|c|}
\hline $\begin{array}{c}\text { Komponen Pelaporan yang } \\
\text { Digunakan }\end{array}$ & $\begin{array}{l}\text { Laporan Keuangan UTD } \\
\text { PMI Kabupaten Pekalongan }\end{array}$ & $\begin{array}{c}\text { Sesuai } \\
\text { Atau } \\
\text { Tidak Sesuai }\end{array}$ & Keterangan \\
\hline $\begin{array}{l}\text { PSAK No 45: } \\
\text { Laporan keuangan } \\
\text { organisasi nirlaba meliputi } \\
\text { laporan posisi keuangan } \\
\text { pada akhir periode laporan, } \\
\text { laporan aktivitas serta } \\
\text { laporan arus kas untuk } \\
\text { suatu periode pelaporan, } \\
\text { dan catatan atas laporan } \\
\text { keuangan. }\end{array}$ & $\begin{array}{l}\text { Laporan keuangan UTD PMI } \\
\text { Kabupaten Pekalongan } \\
\text { terdiri dari laporan posisi } \\
\text { keuangan, laporan aktivitas, } \\
\text { laporan perubahan aset neto, } \\
\text { laporan arus kas, dan catatan } \\
\text { atas laporan keuangan. }\end{array}$ & Sesuai & $\begin{array}{l}\text { Komponen } \\
\text { pelaporan yang } \\
\text { digunakan UTD } \\
\text { PMI Kabupaten } \\
\text { Pekalongan sama } \\
\text { dengan komponen } \\
\text { pelaporan } \\
\text { berdasarkan } \\
\text { PSAK No. } 45 .\end{array}$ \\
\hline
\end{tabular}

Sumber : Data diolah, 2019

Data dari tabel 1 menunjukkan bahwa analisis laporan keuangan UTD PMI Kabupaten Pekalongan yaitu komponen pelaporan yang digunakan terdiri dari laporan posisi keuangan, laporan aktivitas, laporan perubahan aset neto, laporan arus kas, dan catatan atas laporan keuangan. Hal ini telah sesuai dengan PSAK No. 45 yang berisi laporan keuangan organisasi nirlaba meliputi laporan posisi keuangan pada akhir periode laporan (neraca), laporan aktivitas, laporan arus kas serta catatan atas laporan keuangan untuk suatu periode pelaporan.

\subsection{Klasifikasi Aset dan Kewajiban}

Tabel 2.Analisis Klasifikasi Aset dan Kewajiban UTD PMI Kabupaten Pekalongan berdasarkan PSAK No .45

\begin{tabular}{cccc}
\hline & Laporan Keuangan UTD & Sesuai & \\
Klasifikasi Aset dan Kewajiban & PMI Kabupaten & Tidak & Keterangan \\
& Pekalongan & Sesuai & \\
& & & \\
& &
\end{tabular}




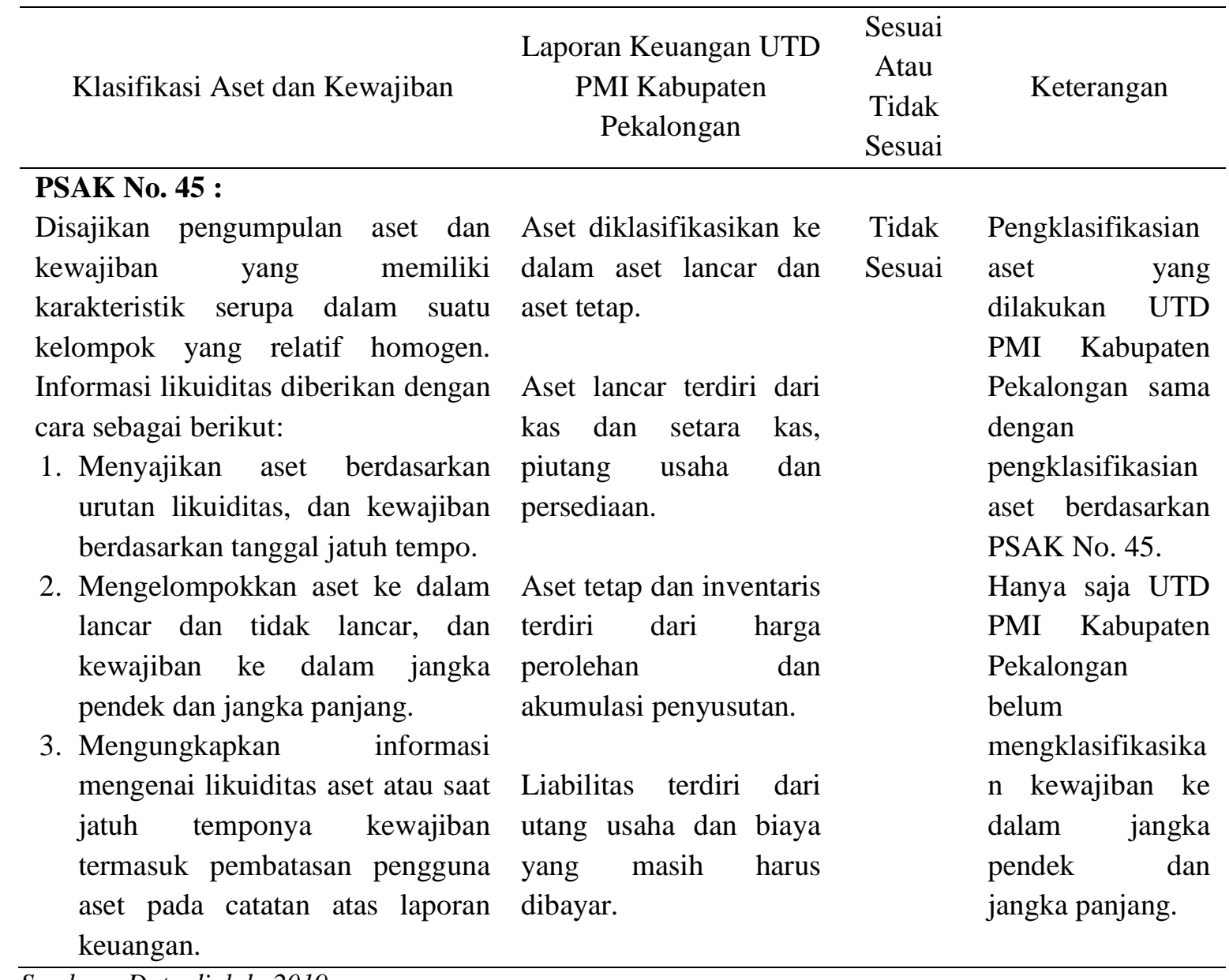

Sumber : Data diolah, 2019

Data dari tabel 2 menunjukkan bahwa analisis laporan keuangan UTD PMI Kabupaten Pekalongan yaitu Klasifikasi Aset dan Kewajiban masih belum sesuai dengan PSAK No. 45, sebab untuk pengklasifikasian kewajiban belum dikelompokkan ke dalam kewajiban jangka pendek dan jangka panjang seperti yang diatur dalam PSAK No. 45, sedangkan untuk pengklasifikasian Aset telah sesuai dengan PSAK No. 45 dimana Aset dikelompokkan ke dalam aset lancar dan tidak lancar.

\subsection{Klasifikasi Aset Bersih Terikat atau Tidak Terikat}

Tabel 3 Analisis Klasifikasi Aset Bersih Terikat atau Tidak Terikat UTD PMI Kabupaten Pekalongan berdasarkan PSAK No. 45

\begin{tabular}{llrl}
\hline \multicolumn{1}{c}{ Klasifikasi Aset dan Kewajiban } & $\begin{array}{c}\text { Laporan Keuangan } \\
\text { UTD PMI Kabupaten } \\
\text { Pekalongan }\end{array}$ & $\begin{array}{c}\text { Sesuai } \\
\text { Atau } \\
\text { Tidak } \\
\text { Sesuai }\end{array}$ & Keterangan \\
\hline PSAK No. 45 : & & neto & Sesuai \\
$\begin{array}{l}\text { Laporan posisi keuangan menyajikan } \\
\text { jumlah masing-masing kelompok aset } \\
\text { bersih berdasarkan ada atau tidaknya }\end{array}$ & $\begin{array}{l}\text { Aset diklasifikasi-kan } \\
\text { dalam aset neto tidak }\end{array}$ & $\begin{array}{l}\text { Pent bersih terikat } \\
\text { atau tidak terikat }\end{array}$ \\
\hline
\end{tabular}




\begin{tabular}{|c|c|c|c|}
\hline Klasifikasi Aset dan Kewajiban & $\begin{array}{c}\text { Laporan Keuangan } \\
\text { UTD PMI Kabupaten } \\
\text { Pekalongan }\end{array}$ & $\begin{array}{c}\text { Sesuai } \\
\text { Atau } \\
\text { Tidak } \\
\text { Sesuai }\end{array}$ & Keterangan \\
\hline $\begin{array}{l}\text { pembatasan oleh penyumbang, yaitu: } \\
\text { Terikat secara permanen, terikat secara } \\
\text { temporer, dan tidak terikat. } \\
\text { Informasi mengenai sifat dan jumlah } \\
\text { dari pembatasan permanen atau } \\
\text { temporer diungkapkan dengan cara } \\
\text { menyajikan jumlah tersebut dalam } \\
\text { laporan keuangan atau dalam catatan } \\
\text { atas laporan keuangan. }\end{array}$ & $\begin{array}{ll}\text { terikat, } & \text { terikat } \\
\text { temporer dan } & \text { terikat } \\
\text { permanen. } & \end{array}$ & & $\begin{array}{l}\text { pada laporan } \\
\text { posisi keuangan } \\
\text { UTD PMI } \\
\text { Kabupaten } \\
\text { Pekalongan sama } \\
\text { dengan } \\
\text { pengklasifikasian } \\
\text { laporan posisi } \\
\text { keuangan } \\
\text { berdasarkan } \\
\text { PSAK No. } 45 .\end{array}$ \\
\hline
\end{tabular}

Data dari tabel 3 menunjukkan bahwa analisis laporan keuangan UTD PMI Kabupaten Pekalongan yaitu Klasifikasi Aset Bersih terikat atau Tidak Terikat telah sesuai dengan PSAK No. 45 yang menyajikan jumlah masing-masing kelompok aset bersih berdasarkan ada atau tidaknya pembatasan oleh penyumbang, yaitu dikelompokkan ke dalam Aset neto tidak terikat, terikat temporer dan terikat permanen.

\subsection{Perubahan Kelompok Aset Bersih}

Tabel 4 Analisis Perubahan Kelompok Aset Bersih UTD PMI Kabupaten Pekalongan berdasarkan PSAK No. 45

\begin{tabular}{cccc}
\hline & Sesuai & \\
Perubahan Kelompok Aset Bersih & Laporan Keuangan UTD & Atau & Keterangan \\
& PMI Kabupaten & Tidak & \\
& Pekalongan & Sesuai & \\
\hline
\end{tabular}

PSAK No. 45 :

Laporan aktivitas menyajikan jumlah perubahan aset bersih terikat permanen, terikat temporer dan tidak terikat dalam suatu periode
Dalam laporan perubahan Sesuai aset neto terdiri dari aset neto tidak terikat yang menyajikan jumlah pendapatan tidak terikat, aset neto yang dibebaskan dari pembatasan dan jumlah beban tidak terikat yang mempengaruhi perubahan jumlah aset neto.

Dengan adanya
kenaikan
(penurunan) aset
neto pada laporan
aktivitas UTD
PMI Kabupaten
Pekalongan maka
sudah sesuai
dengan perubahan
kelompok aset
bersih
berdasarkan
PSAK No. 45

Dengan adanya kenaikan (penurunan) aset neto pada laporan aktivitas UTD PMI Kabupaten Pekalongan maka sudah sesua dengan perubahan kelompok ase berdasarkan PSAK No. 45 
Data dari tabel 4 menunjukkan bahwa analisis laporan keuangan UTD PMI Kabupaten Pekalongan telah sesuai dengan PSAK No. 45 yaitu menyajikan jumlah perubahan aset bersih terikat permanen, terikat temporer dan tidak terikat dalam suatu periode.

\subsection{Klasifikasi Pendapatan, Beban, Keuntungan dan Kerugian}

Tabel 5 Analisis Klasifikasi Pendapatan, Beban, Keuntungan dan Kerugian UTD PMI Kabupaten Pekalongan berdasarkan PSAK No.45

\begin{tabular}{|c|c|c|c|}
\hline $\begin{array}{c}\text { Klasifikasi Pendapatan, Beban, } \\
\text { Keuntungan dan Kerugian }\end{array}$ & $\begin{array}{c}\text { Laporan Keuangan UTD } \\
\text { PMI Kabupaten } \\
\text { Pekalongan }\end{array}$ & $\begin{array}{l}\text { Sesuai } \\
\text { Atau } \\
\text { Tidak } \\
\text { Sesuai }\end{array}$ & Keterangan \\
\hline $\begin{array}{l}\text { PSAK No. 45: } \\
\text { Laporan aktivitas menyajikan } \\
\text { pendapatan sebagai penambah } \\
\text { aset bersih tidak terikat, kecuali } \\
\text { jika penggunannya dibatasi oleh } \\
\text { penyumbang, dan menyajikan } \\
\text { beban sebagai pengurang aset } \\
\text { bersih tidak terikat. } \\
\text { Sumbangan disajikan sebagai } \\
\text { penambah aset bersih tidak } \\
\text { terikat, terikat permanen, atau } \\
\text { terikat temporer, tergantung pada } \\
\text { ada tidaknya pembatasan. Dalam } \\
\text { hal sumbangan terikat yang } \\
\text { pembatasannya tidak berlaku lagi } \\
\text { dalam periode yang sama, dapat } \\
\text { disajikan sebagai sumbangan } \\
\text { tidak terikat sepanjang disajikan } \\
\text { secara konsisten dan diungkapkan } \\
\text { sebagai kebijakan akuntansi. } \\
\text { Laporan aktivitas menyajikan } \\
\text { keuntungan dan kerugian yang } \\
\text { diakui dari investasi dan aset lain } \\
\text { (atau kewajiban) sebagai } \\
\text { penambah atau pengurang aset } \\
\text { bersih tidak terikat, kecuali jika } \\
\text { penggunannya dibatasi }\end{array}$ & $\begin{array}{l}\text { Laporan aktivitas } \\
\text { menyajikan: } \\
\text { 1. Pendapatan dan } \\
\text { Penghasilan sebagai } \\
\text { penambah aset neto } \\
\text { yang terdiri dari } \\
\text { sumbangan, jasa } \\
\text { pelayanan, jasa } \\
\text { pelayanan lainnya dan } \\
\text { penghasilan inventaris. } \\
\text { 2. Aset neto yang berakhir } \\
\text { pembatasannya yang } \\
\text { terdiri dari pemenuhan } \\
\text { program pembatasan, } \\
\text { pemenuhan pembatasan } \\
\text { pemerolehan aset tetap } \\
\text { dan berakhirnya waktu } \\
\text { pembatasan. } \\
\text { 3. Beban dan Kerugian } \\
\text { sebagai pengurang aset } \\
\text { neto yang terdiri dari } \\
\text { beban operasional, } \\
\text { beban manajemen dan } \\
\text { umum serta beban non } \\
\text { operasional. }\end{array}$ & Sesuai & $\begin{array}{l}\text { Pengklasifikasian } \\
\text { Pendapatan, } \\
\text { Beban, } \\
\text { Keuntungan dan } \\
\text { Kerugian pada } \\
\text { pelaporan } \\
\text { keuangan UTD } \\
\text { PMI Kabupaten } \\
\text { Pekalongan sama } \\
\text { dengan } \\
\text { Klasifikasi } \\
\text { Pendapatan, } \\
\text { Beban, } \\
\text { Keuntungan dan } \\
\text { Kerugian } \\
\text { berdasaarkan } \\
\text { PSAK No.45 }\end{array}$ \\
\hline
\end{tabular}

Data dari tabel 5 menunjukkan bahwa analisis laporan keuangan UTD PMI Kabupaten Pekalongan yaitu Klasifikasi
Pendapatan, Beban, Keuntungan, dan Kerugian telah sesuai dengan PSAK No. 45 yang menyajikan pendapatan sebagai penambah aset 
bersih tidak terikat, kecuali jika penggunannya dibatasi oleh penyumbang, dan menyajikan beban sebagai pengurang aset bersih tidak terikat serta Laporan aktivitas menyajikan kerugian yang diakui dari investasi dan aset lain (atau kewajiban) sebagai penambah atau pengurang aset bersih tidak terikat, kecuali jika penggunannya dibatasi.

\subsection{Informasi Pendapatan dan Beban}

Tabel 6 Analisis Informasi Pendapatan dan Beban

UTD PMI Kabupaten Pekalongan berdasarkan PSAK No.45

\begin{tabular}{|c|c|c|c|}
\hline $\begin{array}{c}\text { Informasi Pendapatan dan } \\
\text { Beban }\end{array}$ & $\begin{array}{c}\text { Laporan Keuangan UTD } \\
\text { PMI Kabupaten } \\
\text { Pekalongan }\end{array}$ & $\begin{array}{l}\text { Sesuai } \\
\text { Atau } \\
\text { Tidak } \\
\text { Sesuai }\end{array}$ & Keterangan \\
\hline $\begin{array}{l}\text { PSAK No. } 45 \text { : } \\
\text { Laporan aktivitas menyajikan } \\
\text { jumlah pendapatan dan beban } \\
\text { secara bruto. Namun demikian } \\
\text { pendapatan investasi dapat } \\
\text { disajikan secara neto dengan } \\
\text { syarat beban-beban terkait, seperti } \\
\text { beban penitipan dan beban } \\
\text { penasihat investasi. }\end{array}$ & $\begin{array}{l}\text { Dalam laporan aktivitas } \\
\text { disajikan jumlah } \\
\text { pendapatan secara bruto } \\
\text { yang mengakibatkan } \\
\text { penambahan aset neto, } \\
\text { dan beban yang } \\
\text { mengakibatkan penurunan } \\
\text { aset neto. }\end{array}$ & Sesuai & $\begin{array}{l}\text { Informasi } \\
\text { pendapatan dan } \\
\text { beban pada UTD } \\
\text { PMI Kabupaten } \\
\text { Pekalongan sama } \\
\text { dengan Informasi } \\
\text { pendapatan dan } \\
\text { beban } \\
\text { berdasarkan } \\
\text { PSAK No. } 45\end{array}$ \\
\hline
\end{tabular}

Sumber : Data diolah, 2019

Data dari tabel 6 menunjukkan bahwa analisis laporan keuangan UTD PMI Kabupaten Pekalongan telah sesuai dengan PSAK No. 45 yaitu Laporan aktivitas menyajikan jumlah pendapatan dan beban secara bruto.

\subsection{Informasi Pemberian Jasa}

Tabel 7 Analisis Informasi Pemberian Jasa

UTD PMI Kabupaten Pekalongan berdasarkan PSAK No. 45

\begin{tabular}{|c|c|c|c|}
\hline Informasi Pemberian Jasa & $\begin{array}{c}\text { Laporan Keuangan UTD } \\
\text { PMI Kabupaten } \\
\text { Pekalongan }\end{array}$ & $\begin{array}{l}\text { Sesuai } \\
\text { Atau } \\
\text { Tidak } \\
\text { Sesuai }\end{array}$ & Keterangan \\
\hline $\begin{array}{l}\text { PSAK No. } 45 \text { : } \\
\text { Laporan aktivitas atau catatan atas } \\
\text { laporan keuangan } \\
\text { menyajikan informasi } \\
\text { beban mengenai } \\
\text { fungsional, seperti } \\
\text { kelompok program jasa utama dan } \\
\text { aktivitas pendukung. }\end{array}$ & $\begin{array}{l}\text { Laporan aktivitas dan } \\
\text { catatan atas laporan } \\
\text { keuangan menyajikan } \\
\text { informasi beban menurut } \\
\text { klasifikasi fungsionalnya, } \\
\text { yaitu beban operasional, } \\
\text { beban manajemen dan }\end{array}$ & Sesuai & $\begin{array}{l}\text { Informasi } \\
\text { pemberian jasa } \\
\text { yang digunakan } \\
\text { pada pelaporan } \\
\text { keuangan UTD } \\
\text { PMI Kabupaten } \\
\text { Pekalongan sama }\end{array}$ \\
\hline
\end{tabular}




$\begin{array}{ll}\text { umum dan beban non } & \text { dengan informasi } \\ \text { operasional. } & \text { pemberian jasa } \\ & \text { berdasarkan } \\ & \text { PSAK No.45 }\end{array}$

Sumber : Data diolah, 2019

Data dari tabel 7 menunjukkan bahwa analisis laporan keuangan UTD PMI Kabupaten Pekalongan telah sesuai dengan PSAK No. 45 yaitu Laporan aktivitas atau catatan atas laporan keuangan menyajikan

informasi mengenai beban menurut klasifikasi fungsional, seperti menurut kelompok program jasa utama dan aktivitas pendukung.

\subsection{Klasifikasi Penerimaaan dan Pengeluaran Kas}

Tabel 8.Analisis Klasifikasi Penerimaan dan Pengeluaran Kas UTD PMI Kabupaten Pekalongan berdasarkan PSAK No. 45

\begin{tabular}{cccc}
\hline Klasifikasi Penerimaaan dan & Laporan Keuangan & Sesuai & \\
Pengeluaran Kas & Atau & \multirow{2}{*}{ Keterangan } \\
& Pekalongan & Tidak & \\
& & Sesuai & \\
\hline
\end{tabular}

PSAK No. 45 :

Laporan arus kas disajikan sesuai PSAK No. 2 tentang Laporan Arus Kas dengan tambahan berikut ini: 1.Aktivitas pendanaan :

a. Penerimaan kas penyumbang kas dari pengounaannya dibatasi untuk jangka panjang

b. Penerimaan kas dari sumbangan dan penghasilan investasi yang penggunaannya dibatasi untuk perolehan, pembangunan dan pemeliharaan aset tetap, atau peningkatan dana abadi (endowment).

c. Bunga dan dividen yang dibatasi penggunaannya untuk jangka panjang.

Pengungkapan informasi mengenai aktivitas investasi dan pendanaan nonkas : sumbangan berupa bangunan atau aset investasi.
Berdasarkan kegiatan operasional UTD PMI Kabupaten

Pekalongan, laporan arus kas menyajikan:

1. Arus kas dari aktivitas operasi meliputi:

a. Arus kas masuk

b. Arus kas keluar

2.Arus kas dari aktivitas investasi meliputi:

a. Arus kas masuk

b. Arus kas keluar

3. Arus kas dari aktivitas pendanaan meliputi:

a. Arus kas masuk

b. Arus kas keluar
Sesuai

Pada PSAK No. 45 terdapat pos rekonsiliasi perubahan dalam aset bersih menjadi kas bersih yang digunakan untuk menambah aktivitas operasi yang tidak diperlukan dalam laporan keuangan UTD PMI

Kabupaten

Pekalongan.

Sumber : Data diolah, 2019 
Data dari tabel 8 menunjukkan bahwa analisis laporan keuangan UTD PMI Kabupaten Pekalongan yaitu klasifikasi Penerimaan dan pengeluaran kas telah sesuai dengan PSAK No. 45, namun pada PSAK No 45 terdapat rekonsiliasi perubahan asset bersih menjadi kas bersih yang digunakan untuk menambah aktivitas operasi, sedangkan pada laporan keuangan Unit Transfusi darah PMI Kabupaten Pekalongan tidak diperlukan.

\section{KESIMPULAN DAN SARAN}

\subsection{Kesimpulan}

Berdasarkan hasil penelitian yang telah dilaksanakan maka dapat ditarik kesimpulan bahwa: secara keseluruhan, UTD PMI Kabupaten Pekalongan telah mengacu pada ketentuan PSAK No. 45 tentang pelaporan keuangan organisasi nirlaba, namun ada 1 indikator dalam laporan keuangan UTD PMI Kabupaten Pekalongan yang tidak sesuai dengan PSAK No. 45, yaitu klasifikasi kewajiban (hutang) yang belum dikelompokkan ke dalam kewajiban (hutang) baik jangka pendek maupun jangka panjang.

\subsection{Saran}

Unit Transfusi Darah (UTD) PMI Kabupaten Pekalongan sebaiknya melakukan pengklasifikasian terhadap kewajiban, sehingga UTD PMI Kabupaten Pekalongan dapat dikatakan sepenuhnya telah menerapkan PSAK No.45. UTD PMI Kabupaten Pekalongan diharapkan dapat terus mengikuti perkembangan peraturan penyajian laporan keuangan khususnya PSAK No. 45 yang dapat diperbaharui kapan saja sesuai dengan perkembangan zaman.

\section{Daftar Pustaka}

Aji, I.B.M.C.R. 2017.Analisis Penerapan Psak No. 45 Tentang Pelaporan Keuangan Organisasi Nirlaba Pada Rumah Sakit Berstatus Badan Layanan Umum.
Skripsi.Fakultas Ekonomi Universitas Negeri Yogyakarta.

Akuntansi Organisasi Nirlaba. 2013. Laporan Keuangan Organisasi Nirlaba.

Angelia N.M. Tinungki., R.J. Pusung. 2014. Penerapan Laporan Keuangan Organisasi Nirlaba Berdasarkan PSAK No 45 Pada Panti Sosial Tresna Werdha Hana. Unsrat Manado: Jurnal Emba.

Andarsari, P. R. (2016). Laporan Keuangan Organisasi Nirlaba (Lembaga Masjid). Jurnal Ekonomi Universitas Kadiri, 1(2), 143-152.

Asdar, Ludigdo, U., \& Widya.P, Y. (2014). Phenomenological Study Of Financial Accountability Of Mosque. Iosr Journal Of Economics And Finance (Iosr-Jef), 5(4), 10-17.

Bastian,Indra.(2010).Akuntansi Sektor Publik: Suatu Pengantar.Jakarta:Erlangga.

Coate, C. J., \& Mitschow, M. C. (2018). Luca Pacioli And The Role Of Accounting And Business : Early Lessons In Social Responsibility. Research On Professional Responsibility And Ethics In Accounting, (August). Https://Doi.Org/10.1108/S1574076520180000021001

European Commission. (2011). International Accounting Standard 1 Presentation Of Financial Statements.

European Commission Staff Consolidated Version, (February), 1-23.

Fahmi, F. A., \& Qulub, A. S. (2017). Pelaksanaan Fungsi Manajemen (Planning, Organizing, Actualling, Controlling) Pada Manajemen Masjid AlAkbar Surabaya. Jurnal Ekonomi Syariah Teori Dan Terapan, 4(1), 968-976.

Geijsbeek, J. B. (1914). Ancient Double Entry Bookkepping Lucas Pacioli's Creatise 
(A.D. 1494 - The Ealiest Known Writer On Bookkepping) Re-Produced And Translated With Reproductions, Notes, And Abstracts From Manzoni, Pietra, Mainardi, Ympyn, Stebin, And Dafforne. Denver, Colorado: John B. Geijsbeek.

Global Religious Futures. (2016). Religious Demography: Affiliation (2010 All Religious Groups) Restrictions On Religion (2016 - All Countries ). Retrieved From

Www.Globalreligiousfutures.Org

Hendrawan, R., \& Kiswara, E. (2011). Analisis Penerapan Psak No. 45 Tentang Pelaporan Keuangan Organisasi Nirlaba Pada Rumah Sakit Berstatus Badan Layanan Umum. Akuntansi Dan Investasi, (45).

Ikatan Akuntan Indonesia (IAI). 2010. PSAK No.45: Akuntansi Organisasi Nirlaba. Jakarta: Ikatan Akuntan Indonesia.

Indriantoro, Nur, dan Bambang Supomo. 1999. Metodologi Penelitian dan Bisnis, Yogyakarta: BPFE Yogyakarta.

IAI. (2016). Standar Akuntansi Keuangan Efektif Per 1 Januari 2017.Jakarta:Ikatan Akuntansi Indonesia. Julianto, E., Affan, N., \& Diyanti, F. (2017). Analisis Penerapan Psak No.45. Jurnal Fakultas Ekonomi

Ikatan Akuntan Indonesia (IAI). 2010. PSAK No.45: Akuntansi Organisasi Nirlaba. Jakarta: Ikatan Akuntan Indonesia.

Ikatan Akuntan Indonesia. 2011. Pernyataan StandarAkuntansi Keuangan Nomor 45 (Revisi 2011) tentangPelaporan Keuangan Entitas Nirlaba. Jakarta: Salemba Empat.

Peraturan Menteri Kesehatan Republik Indonesia Nomor 83 Tahun 2014 Tentang Unit Transfusi Darah, Bank Darah Rumah Sakit dan Jejaring Pelayanan Transfusi Darah.
Pontoh, Chenly Ribka. 2013. Penerapan Laporan Keuangan Organisasi Nirlaba Berdasarkan PSAK No 45 pada Gereja BZL. Unsrat Manado: Jurnal Emba.

Shahaeuddin, S. B., \& Sualiman, M. B. (2015). Financial Disclosure And Budgetary Practices Of Religious Organization: A Study Of Qaryah Mosques In Kuala Terengganu. Gadjah Mada International Journal Of Business, 17(1), 83-101.

Siskawati, E., Ferdawati, \& Surya, F. (2016). Bagaimana Masjid Dan Masyarakat Saling Memakmurkan? Pemaknaan Akuntabilitas Masjid. Jurnal Akuntansi Multiparadigma Jamal, 7(April), 70-80. Https://Doi.Org/10.18202/Jamal.2016.04. 7006

Sriwardiningsih, E. (2014). Nilai Guna ( Kepuasan ) Green Technology E-Toll Sebagai Salah Satu Alternatif Layanan Pada Konsumen Pengguna Tol Dalam Kota Jakarta. Binus Universityjournal, 5, 323-332. Retrieved From Http://Journal.Binus.Ac.Id/Index.Php/Bbr/ Article/View/1255

Sugiyono (2017). Metodelogi Penelitian Kuantitatif, Kualitatif, Dan R\&D.Bandung:Penerbit Alfabeta. Suryono, B. (1999). Organisasi Nirlaba: Karakteristik Dan Pelaporan Keuangan Organisasi.

Seven Audi Sapta.2009. Kenali PMI di https://wiki.openstreetmap.org (Diakses 4 April 2019).

Wahyu, Grace dan Heince. 2015. Penerapan Laporan Keuangan Organisasi Nirlaba Berdasarkan PSAK No 45 Pada Stikes Muhammadiyah Manado. Unsrat Manado: Jurnal Emba. 